\title{
Interaction of Some Plant Extracts with Some Antibiotics against Salmonella from Chickens
}

\author{
Ashraf A. Abd-El Tawab ${ }^{1}$, Ahmed M. Ammar ${ }^{2}$, Ahmed M. Hamouda ${ }^{3}$, \\ Wafaa A. EL Sebaey ${ }^{4}$, Safinaz A.M. Elhawary ${ }^{5}$ and Salma S. El-Deen ${ }^{4 *}$
}

${ }^{1}$ Department of Bacteriology, Immunology and Mycology, Faculty of Veterinary Medicine, Benha University, Moshtoher, Qalyubiyagovernate, Egypt

${ }^{2}$ Department of Bacteriology, Immunology and Mycology, Faculty of Veterinary Medicine, Zagazig University, Zagazig, Sharkiagovernate, Egypt

${ }^{3}$ Animal Health Research Institute Zagazig, Sharkiagovernate, Egypt

${ }^{4}$ Animal Health Research, Dokki, Giza, Egypt

${ }^{5}$ Faculty of Veterinary Medicine, Benha University, Qalyubiyagovernate, Egypt

*Corresponding author

\section{A B S T R A C T}

Multidrug-resistant bacterial strains are becoming a serious problem. Therefore, the application of natural antimicrobial agents from plant extracts combined with antibiotics to overcome this problem is of major importance. The antimicrobial activity of five plants (Rosemary, Marjoram, Mint, Dill and Neem) methanol extract prepared by ultrasonicassisted (UAE) combined with antibiotics (amoxicillin, doxycycline, gentamicin and difloxacin) against 41 Salmonella poultry isolates was tested using in vitro methods. The interactions between plant extracts and antibiotics are known to be either additive or synergistic or antagonistic. The mean zones of inhibition ( $\mathrm{mm}$ ) and the minimum inhibitory concentration (MIC) of plant extracts and of antibiotics and combination between them was determined. The total phenolic content (TPC) and the antioxidant activity (DPPH·) of plant extracts was evaluated. Methanol extracts had high total phenolic compounds which used as a source of natural antioxidants. The results revealed that synergistic effects appear in rosemary with amoxicillin and gentamicin and difloxacin, dill with doxycycline and gentamicin, also neem with amoxicillin and doxycycline. Synergistic activity against Gram-negative bacteria demonstrated that extracts could be a source of bioactive substances with a broad spectrum of antibacterial activity especially when combined with antibiotics. In addition, extracts are potential safe sources of bioactive compounds, antioxidants, antibacterial agents which might be applied in different foods and pharmaceutical products.

\section{Introduction}

Antimicrobial resistance is one of the most common serious threats facing poultry industry as it can transfer to other pathogenic bacteria, causing a compromise in the treatment of severe infections (Enayat et al., 2013; Stefanovic and Comic, 2012). This 
problem has encouraged scientists to search for new alternatives to antibiotics (CDC, 2013).

Gram-negative bacteria are more resistant to antibiotics than the Gram-positive bacteria due to the permeability barrier provided by the cell wall or to the membrane accumulation mechanism (Mounia et al., 2010). To overcome this problem, some medicinal plants, as source for multidrug resistance inhibitors (Eze et al., 2013), were utilized in combination with antibiotics in vitro as antimicrobial agents.

The MIC is the lowest concentration of an antimicrobial that will inhibit the visible growth of a microorganism by overnight incubation, usually reported as $\mathrm{mg} / \mathrm{L}$ (Delaquis et al., 2002). It represents a monitor for resistance to antimicrobial agents and is carried out by broth dilution methods (Handa et al., 2008).

Nowadays, to overcome environmental pollution caused by plant residues, numerous studies focused on recovering, recycling of plant residues as it has potential biological effects (Cioffi et al., 2009; Gavaric et al., 2015).

About $99 \%$ of plant residues after extraction are rich with secondary metabolites and bioactive compounds including natural antioxidants and phenolic compounds which play an important role in protection against infection, preventing oxidation and degenerative diseases (Singleton et al., 1965; Valko et al., 2006; Zhao and Gao, 2014).

This study was carried out to evaluate the interaction of some plant extracts with some antibiotics against Salmonella from chickens and to determine MIC for each antibiotic and plant extracts by using DAA method to detect the effect of interaction between antibiotics and plant extracts.

\section{Materials and Methods}

\section{Bacterial strains}

\section{Standard strain (ATCC)}

The tested Salmonella were provided from the culture collections of the Microbiological Department, National Research Center (NRC) Dokki, Giza, Egypt.

\section{Field strain}

41 isolates out of 120 diseased poultry samples which isolated from different poultry farms in Dakahlia governorates (Mahtet Elsalam, Mahtet El-Aml, Tawonya) and in Sharkia governorates (Gamsa, Sherbin, Elsalehia project).

\section{Plants}

\section{Plant materials}

Five plant including rosemary (Rosmarinus officinalis) leaves, marjoram (Origanum majorana) leaves, mint (Mentha spicata) leaves, dill (Anethum graveolens) seeds, neem (Azadirachta meliaceae) leaves were obtained from Faculty of Agriculture, Zagazig University (Egypt).

Preparation of the ultrasonic-assist methanol $(80 \%)$ extract

Extraction was performed by ultrasound to overcome (time-solvent) consuming and increase extraction efficiency according to Betancount (2008).

\section{Isolation and identification of the suspected bacteria}

Research Institute Zagazig lab, 41 poultry samples were subjected to biochemical identification as described by Harley and Prescott (2002). 


\section{Antimicrobial susceptibility testing}

\section{Disk Diffusion Method}

This was performed according to guidelines set by the Clinical Laboratory Standards Institute CLSI (2010). The diameters of the zones of inhibition were measured in millimeter and classified as resistant, intermediate or sensitive. The assay was repeated using plant extract alone, antibiotics alone or combination between them by disk diffusion method to detect the effect of ten standard antibiotic discs and five selected extracts (Oxoid®) against Salmonella according to Bauer et al., (1966).

\section{Minimal inhibitory concentration (MIC)}

The isolated strains matched the 0.5 McFarland standard $\left(1.5 \times 10^{5} \mathrm{CFU} \mathrm{mL} \mathrm{mL}^{-1}\right)$ and results of antibiotics and/or extracts showed no visible bacterial growth were considered as MIC and interpreted with recommendations of the National Committee for Clinical Laboratory standards Lorian (1996), Adam et al., (1998) and Dorman and Deans (2000).

Evaluation of the combined activity of antibiotics and extracts using Decimal Assay for Additivity (DAA)

The evaluation was performed as described by Sanders et al., (1993) to detect end point for additivity so that interactions greater or less than additivity defined as synergism and antagonism respectively.

\section{Determination of total phenolic compounds (TPC)}

TPC was measured using UV spectrophotometer according to Škerget et al., (2005) using Folin-Ciocalteu reagent. The results were expressed as $\mathrm{mg}$ gallic acid equivalents (GAE) per gram of dry weight (mg GAE g-1 DW) using a calibration curve and the yield of extracts $(\mathrm{g} / 100 \mathrm{~g})$.

\section{Antioxidant DPPH $^{-}$radical-scavenging activity}

The ability of extracts for electron donation was measured by bleaching of the purple colored solution of DPPH- (2,2-diphenyl-1picrylhydrazyl) to the yellow color as described by Gulcin et al., (2004). The color intensity varies according to the amount of oxidant in the sample. The absorbance of this color was measured spectrophotometrically at $530 \mathrm{~nm}$ (Dikilitas et al., 2011).

\section{Results and Discussion}

The study focused on the incidence of Salmonella in a total of 120 samples that were aseptically collected from visceral organs, as samples revealed 41 Salmonella out of 120 specimens with percentages of (34.2\%) respectively in Table 1.

For further identification of Gram-negative isolates, biochemical tests such as IMViC were used under standard conditions which discussed in Table 2.

Salmonella showed negative results with Indole and V.P and positive result with Citrate and M.R.

Antimicrobial susceptibility testing showed the highest sensitivity rate of Salmonella strains that recorded to fluorophenol, cefotaxime and colistin (29, 18, and 14\%, respectively) of sensitive strains and the highest intermediate rate was recorded to colistin, difloxacin a gentamicin $(26,21$, and $18 \%$, respectively) of intermediate strains and the highest resistant rate was recorded to erythromycin, amoxycillin and doxycycline $(33,22$, and $20 \%$, respectively) as shown in Table 3. 
The clear zones around four antibiotic discs indicated organism's inability to survive in the presence of the test antibiotic antibacterial activity of natural antimicrobial agents (Rosemary, Marjoram, Peppermint, Dill and Neem) with the lowest concentration had a $10,15,12,15$ and $14 \mathrm{~mm}$, respectively.

On the other hand, antibiotics (amoxicillin, doxycycline, gentamycin, difloxacin) exhibited different I.Z from 14 to $15 \mathrm{~mm}$ for amoxycilin, 0-16 $\mathrm{mm}$ for doxycycline, $13 \mathrm{~mm}$ for gentamycin and 18-23 mm for difloxacin against field isolated Salmonella in Table 4.

In this study, every 4 antibiotics and 5 plant extracts were subjected to a broth macrodilution assay and after $24 \mathrm{~h}$, observation of Salmonella bacterial growth to determine the MIC values.

The result of minimum inhibitory concentration on field strain is compared with their results on standard strain as rosemary (0.5 $\mu \mathrm{g}$ on field and $0.25 \mu \mathrm{g}$ on standard), peppermint $(32 \mu \mathrm{g}$ on field and $8 \mu \mathrm{g}$ on standard), majoram ( $8 \mu \mathrm{g}$ on field and $4 \mu \mathrm{g}$ on standard $)$, dill $(4 \mu \mathrm{g}$ on field and $1 \mu \mathrm{g}$ on standard), neem was (64 $\mu \mathrm{g}$ on field and $8 \mu \mathrm{g}$ on standard) as shown in Table 5.

The result of minimum inhibition concentration of antibiotics on field strain is compared with their results on standard strain as AML was $(0.5 \mu \mathrm{g}$ on field and $0.125 \mu \mathrm{g}$ on standard), INN was $(0.25 \mu \mathrm{g}$ on field and $0.06 \mu \mathrm{g}$ on standard), DO was $(1 \mu \mathrm{g}$ on field and $0.5 \mu \mathrm{g}$ on standard), GN was ( $2 \mu \mathrm{g}$ on field and $0.25 \mu \mathrm{g}$ on standard) shown in Table 6.

Antimicrobial activities of methanol extracts in combination with antibiotics on selected Salmonella isolates as Interactions lead to antagonistic, additive and synergistic, as additive observed when the combined effect is equal to the sum of the individual effects, antagonism is observed when the effect of one or both compounds is less when they are applied together then synergism is observed when the effect of the combined substances is greater than the sum of the individual.

Synergistic effect between plant extracts and antibiotics was evaluated by comparing the size of inhibition zone of plant alone and antibiotics alone on Salmonella.

The results revealed that synergistic effects appeared in rosemary with amoxicillin at ratio (7:3) and gentamicin with ratio (7:3) and difloxacin at ratios (7:3) and (6:4), while dill and doxycycline at ratio (7:3), also majorana and gentamicin with ratio (5:5), finally neem with amoxicillin at ratio (5:5) and doxycycline at ratio (5:5) as shown in Table 7.

Table.1 Number of Salmonella isolates obtained from various specimens collected from chicken localities in Sharkia and Dakahlia governorates

\begin{tabular}{|c|c|c|c|}
\hline & Locality & No. of cases & Salmonella \\
\hline & $\begin{array}{c}\text { Private farms } \\
\text { (MahtetElsalam,MahtetElAml,Tawonya) }\end{array}$ & 19 & $\mathbf{6}$ \\
\hline & Private farms (Gamsa, Sherbin) & 18 & $\mathbf{1 2}$ \\
\hline & Farms in Sharkiagovernate & 15 \\
\hline \\
\hline
\end{tabular}


Table. 2 Biochemical characteristics of isolated bacteria by the IMViC results of some species

\begin{tabular}{|l|l|c|c|c|}
\hline \multicolumn{1}{|c|}{ Specie } & Indole & Methyl red & Voges-Proskauer & Citrate \\
\hline Escherichia coli & Positive & Positive & Negative & Negative \\
\hline Klebsiella spp. & Negative & Negative & Positive & Positive \\
\hline Salmonella spp. & Negative & Positive & Negative & Positive \\
\hline Shigella spp. & Negative & Positive & Negative & Negative \\
\hline Proteus mirabilis & Negative & Positive & Negative & Positive \\
\hline Citrobacterfreundii & Negative & Positive & Negative & Positive \\
\hline
\end{tabular}

Table.3 Antimicrobial susceptibility of Salmonella spp. $(\mathrm{n}=79)$ by agar disc diffusion method

\begin{tabular}{|l|c|c|c|c|}
\hline \multicolumn{1}{|c|}{ Antimicrobial agent } & Trade name & S & I & R \\
\hline Amoxicillin & AML & 6 & 13 & 22 \\
\hline Colistin & CT & 14 & 26 & 1 \\
\hline Difloxacin & DIF & 9 & 21 & 11 \\
\hline Doxycyclin & DO & 5 & 16 & 20 \\
\hline Gentamycin & GN & 13 & 18 & 10 \\
\hline Erythromycin & E & -- & 8 & 33 \\
\hline Flurophenicol & F & 29 & 4 & 8 \\
\hline Cefotaxime & CTX & 18 & 4 & 19 \\
\hline Streptomycin & S & 10 & 9 & 22 \\
\hline
\end{tabular}

Table.4 Diameter of I.Z (mm) of antibiotics and extracts as well as combination on Salmonella

\begin{tabular}{|l|c|c|c|c|c|c|c|c|c|}
\hline & \multicolumn{9}{|c|}{ Inhibition zone (mm) } \\
\hline \multirow{2}{*}{ Salmonella } & $\begin{array}{c}\text { Plant } \\
\text { alone }\end{array}$ & \multicolumn{3}{|c|}{ Antibiotics alone } & \multicolumn{5}{c|}{ Combination } \\
\cline { 3 - 12 } & Amoxy & Doxy & Genta & Diflo & Amoxy & Doxy & Genta & Diflo \\
\hline Rosemary & 10 & 14 & --- & 13 & 18 & 19 & --- & 17 & 23 \\
\hline Majoram & 15 & 15 & 13 & 13 & 18 & 15 & --- & 13 & 18 \\
\hline Peppermint & 12 & 14 & --- & 12 & 20 & 10 & --- & 13 & 20 \\
\hline Dill & 15 & 14 & 16 & 13 & 19 & 18 & 18 & 13 & 18 \\
\hline Neem & 14 & 14 & 15 & 13 & 18 & 15 & 18 & 13 & 18 \\
\hline
\end{tabular}


Table.5 Antibacterial Activity of plants extract by Minimal Inhibitory Concentration (MIC) on Salmonella spp

\begin{tabular}{|c|c|c|c|}
\hline & \multicolumn{3}{|c|}{ Salmonella isolate } \\
\hline Plant & \multicolumn{2}{|c|}{ Salmonella } & $\mathrm{MIC}(\mu \mathrm{g} / \mathrm{mL})$ \\
\hline \multirow[t]{2}{*}{ Rosemary } & Field & S.10 & $0.5 \pm 0.41$ \\
\hline & \multicolumn{2}{|c|}{ Standard strain } & $0.25 \pm 0.04$ \\
\hline \multirow[t]{2}{*}{ Pepermint } & Field & S.10 & $32 \pm 3.27$ \\
\hline & \multicolumn{2}{|c|}{ Standard strain } & $8 \pm 1.63$ \\
\hline \multirow[t]{2}{*}{ Majoram } & Field & S.10 & $8 \pm 0.82$ \\
\hline & \multicolumn{2}{|c|}{ Standard strain } & $4 \pm 0.41$ \\
\hline \multirow[t]{2}{*}{ Dill } & Field & S.10 & $4 \pm 1.25$ \\
\hline & \multicolumn{2}{|c|}{ Standard strain } & $1 \pm 0.82$ \\
\hline \multirow[t]{2}{*}{ Neem } & Field & S.10 & $64 \pm 2.49$ \\
\hline & \multicolumn{2}{|c|}{ Standard strain } & $8 \pm 0.82$ \\
\hline
\end{tabular}

Table.6 Antibacterial Activity of antibiotics by Minimal Inhibitory Concentration (MIC) on Salmonella spp

\begin{tabular}{|c|c|c|c|}
\hline & \multicolumn{3}{|c|}{ Salmonella isolates } \\
\hline Antibiotic & \multicolumn{2}{|c|}{ Salmonella } & $\mathrm{MIC} \mu \mathrm{g} / \mathrm{ml}$ \\
\hline \multirow[t]{2}{*}{ AML } & Field & S.10 & 0.5 \\
\hline & \multicolumn{2}{|c|}{ Standard strain } & 0.125 \\
\hline \multirow[t]{2}{*}{ INN } & Field & S.10 & 0.25 \\
\hline & \multicolumn{2}{|c|}{ Standard strain } & 0.06 \\
\hline \multirow[t]{2}{*}{ DO } & Field & S.10 & 1 \\
\hline & \multicolumn{2}{|c|}{ Standard strain } & 0.5 \\
\hline \multirow[t]{2}{*}{ GN } & Field & S. 10 & 2 \\
\hline & \multicolumn{2}{|c|}{ Standard strain } & 0.25 \\
\hline
\end{tabular}


Table.7 Combination activity of antibiotics with extracts using DAA

\begin{tabular}{|c|c|c|c|c|c|c|}
\hline \multicolumn{7}{|l|}{ Salmonella } \\
\hline \multirow[t]{2}{*}{ Plant extracts } & \multirow[t]{2}{*}{ Antibiotics } & \multicolumn{3}{|c|}{ DAA } & \multirow{2}{*}{$\begin{array}{c}\text { MIC } \\
\text { AB alone }\end{array}$} & \multirow[t]{2}{*}{ Effect } \\
\hline & & $\mathrm{AB}$ & $\mathrm{E}$ & DAA & & \\
\hline \multirow[t]{4}{*}{ Rosemary } & a) Amoxycillin & 7 & 3 & 0.125 & 0.5 & Synergy (S) \\
\hline & b) Gentamicin & 7 & 3 & 0.06 & 2 & Synergy (S) \\
\hline & \multirow[t]{2}{*}{ c) Difloxacin } & 7 & 3 & 0.06 & 0.25 & \multirow[t]{2}{*}{ Synergy (S) } \\
\hline & & 6 & 4 & 0.06 & 0.25 & \\
\hline Oregano & a) Gentamicin & 5 & 5 & 1 & 2 & Synergy (S) \\
\hline Dill & a) Doxycycline & 7 & 3 & 0.125 & 1 & Synergy (S) \\
\hline \multirow[t]{2}{*}{ Neem } & a) Amoxycillin & 5 & 5 & 0.06 & 0.5 & \multirow[t]{2}{*}{ Synergy (S) } \\
\hline & b) Doxycycline & 5 & 5 & 0.5 & 1 & \\
\hline
\end{tabular}

Table.8 Total phenolic compounds (mg gallic acid/g extract) in UAE and MAW extracts

\begin{tabular}{|l|c|c|c|}
\hline Plant & Extract yield & \% Extract & TPC (mg GAE/g extract) \\
\hline Dill & 2.04 & 10.2 & $\mathbf{3 6 . 9 6} \pm \mathbf{0 . 8 1}$ \\
\hline Rosemary & 2.68 & 13.4 & $\mathbf{1 8 6 . 2 5} \pm \mathbf{1 . 2 3}$ \\
\hline Marjoram & 3.24 & 16.2 & $\mathbf{1 1 9 . 3 8} \pm \mathbf{0 . 8 3}$ \\
\hline Mint & 2.53 & 12.65 & $\mathbf{1 4 3 . 4 5} \pm \mathbf{1 . 2 2}$ \\
\hline Neem & 4.96 & 24.8 & $\mathbf{3 9 . 3 8} \pm \mathbf{0 . 8 3}$ \\
\hline
\end{tabular}

Figure.1 DPPH· radical scavenging activity of plant extracts, TBHQ and gallic acid

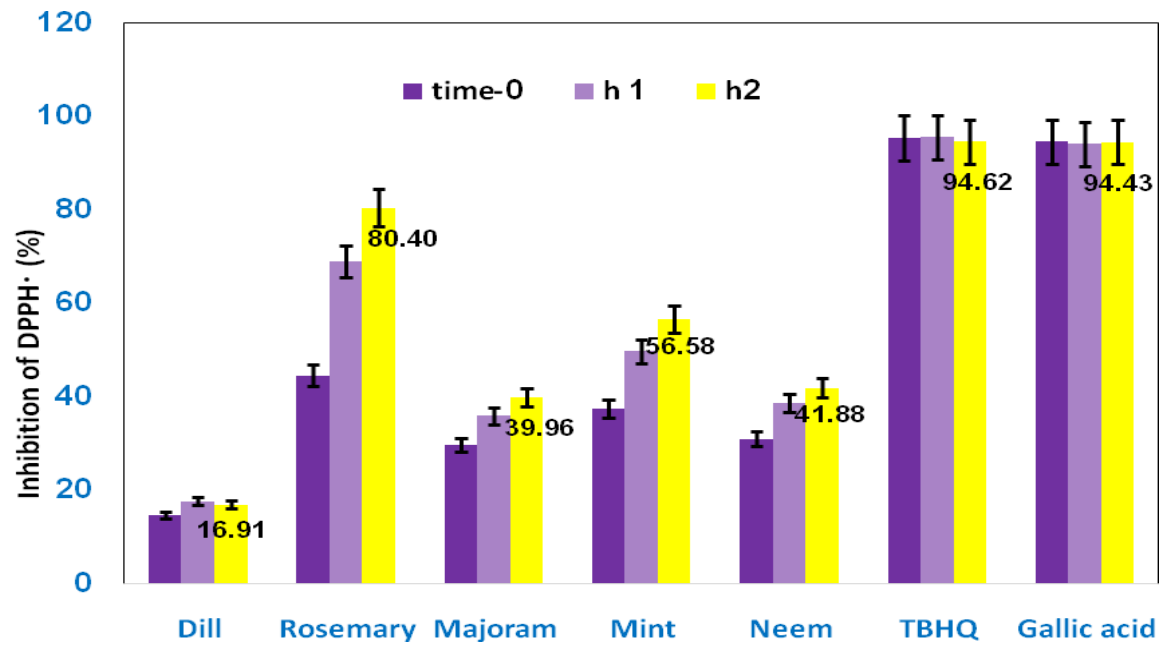


The results proved that extracts contained a high amount of total phenolic compounds that showed high antioxidant activity as rosemary with DPPH activity $80.4 \%$ then followed by mint, neem, marjoram and dill extracts with respective data $56.58 \%, 41.88 \%, 39,96 \%$ and $16.91 \%$, respectively which shown in Table 8 and Figure 1.

Salmonellosis is considered to be the major bacterial disease in poultry industry worldwide. Kabir (2010) and Markov et al., (2009) reported that out $95 \%$ of Salmonella are ingested through food and the most common sources of infection are meat and meat products.

Biochemical tests such as IMViC with recoded results agreed with Hendriksen (2011). Antimicrobial susceptibility testing on clinical veterinary Salmonella strains shows results not similar to Boyen et al., (2010) and contrast with Dong et al., (2014) but it similar to Gonzales et al., (1998) and agree with Sallam et al., (2014). On the other hand this pattern similar to other clinical veterinary Salmonella strains as reported by Threlfall et al., (1996).

The plant extracts had varying degrees of growth inhibition against Salmonella. ZI of rosemary had an average of $10 \mathrm{~mm}$ and similar to Smith et al., (1998) with who reported ZI of $9.3 \mathrm{~mm}$ but not agree with Busatta et al., (2008), while majoram had ZI at an average of $15 \mathrm{~mm}$ which in parallel with Chan et al., (2012). In addition, peppermint had ZI at an average of $12 \mathrm{~mm}$ which in fair correlation with Pattnail et al., (1997) and Sabahat et al., (2006) who reported ZI at an average of $11.78 \mathrm{~mm}$. Dillhad ZI of $15 \mathrm{~mm}$ which agree with Mohammad (2017) who reported ZI of $15 \mathrm{~mm}$, finally neem had ZI of $14 \mathrm{~mm}$ which not agree with Maragathavalli et al., (2012). The synergistic effect was evaluated by comparing the size of the inhibition zone in plates containing plant extracts and in control plates without plant extracts.

On the other hand, the clear zones around each antibiotic discs indicate the extent of the test organism's inability to survive in presence of the test antibiotic with different IZ on Salmonella (14-15mm) around amoxicilin and in parallel with Ramanauskiene et al., (2004), also (13-16 $\mathrm{mm}$ ) around doxycycline that agrees with Moodi Helal et al., (2016); while $13 \mathrm{~mm}$ around gentamycin as not confirmed with Andrea et al., (2009).

The synergistic interaction determined between plant extracts and antibiotics in this study revealed that dill has the highest effect on Gram-negative microorganisms and this contrast with Ljiljana et al., (2016) who reported that dill had the highest effect on Gram-positive. Also, Bakkali et al., (2008) who reported that dill extract is significant for animal pathogens as well as for food protection.

Phenolic substances have been shown to be responsible for the antioxidant activity of plant materials (Kim et al., 2011).

The high antioxidant activity has been positively correlated with the concentration of phenolic compounds in extracts, wherein rosemary and mint had high phenolic compounds with respective values of 186.25 and $143.45 \mathrm{mg}$ GAE extract. On the other hand, rosemary and mint extracts had the strongest scavenging activity of $\mathrm{DPPH}$. free radical with $80.4 \%$ and $56.58 \%$ against synthetic antioxidant (TBHQ) with 94.62\% and gallic acid. Our obtained results were very close to data reported by Bryngelsson et al., (2002), and Sun et al., (2007).

In conclusion synergistic activity by antibiotic and extracts against Gram-negative bacteria demonstrated that plants can be a source of 
bioactive substances with a broad spectrum of antibacterial activity especially when combined with antibiotic. In addition, the methanol extracts have high total antioxidant and phenolic compounds which could be used in pharmaceutical products as a source of natural antioxidants. More research is required to investigate the synergistic capacity of plants with antimicrobial activity.

\section{References}

Adams, C.M., Anderson, M.G., Motto, D.G., Price, M.P., Johnson, W.A. and Welsh, M.J. (1998). Ripped pocket and pickpocket, novel Drosophila $\mathrm{DEG} / \mathrm{ENaC}$ subunits expressed in early development and in mechanosensory neurons. $J$. Cell Biol140 (1), 143-152.

Andrea, G. S., Oscar, C., Piotr, N., Alessandra, R., Agnese, D. A., Wojciech, K., Jerzy, L. and Giorgio, S. (2007).In Vitro Activity of Aurein 1.2 Alone and in Combination with Antibiotics against Gram-positive Nosocomial Cocci. Antimicrob. Agents Chemother., 27(2),171-179.

AOAS (1990). In official methods and recommended practices of the American Oil Chemists Society ( $4^{\text {th }}$ ed). Champaign: American Oil Chemists Society.

Bakkali F, Averbeck S, Averbeck D, Idaomar M. (2008). Biological effects of essential oils--a review. Food Chem Toxicol. 46(2), 446-475.

Bauer, A.W., Kirby, M., Kirby, J., Sherris, C. and Turck, M. (1966). Antibiotic susceptibility testing by a standardized single disc method. Am.J. ClinPatholl45, 493-496.

Betancourt, AO. (2008). Analyse, extraction et récupération de poly-3 hydroxybutyrate présent dans la biomasse. Université du Québec à
Montréal Thesis, pp. 45-55.

Boyen, F., Vangroenweghe, F. and Butaye P. (2010). Disk prediffusion is a reliable method for testing colistin susceptibility in porcine $E$. coli strains. Veterinary Microbiology 144 (3-4), 359-362.

Bryngelson,S., Mannerstedt-Fogelfors, B., Kamal Eldin, A., Andersson, R., and Dimberg, L.H.,(2002).Lipids and antioxidants in groats and hulls of Swedish oats (Avena sativa L.). J Sci Food Agric, 82, 606-614.

Busatta, C., Vidala, R.S., Popiolskia, A.S., Mossia, A.S., Darivab, C., Rodriguesc, M.R.A., Corazzaa, F.C., Corazzaa, M.L., Vladimir, J., Oliveiraa and Cansiana, R.L. (2008). Application of Origanum majorana L. essential oil as an antimicrobial agent in sausage. Food Microbiology25,207211.

Centers for Disease Control and Prevention (CDC), National Center for Health Statistics. (2013). Antibiotic resistance threats in the United States, Apr. Available.

Chan, E.W.C., Kong, L.Q., Yee, K.Y., Chua, W.Y. and Loo, T.Y. (2012). Rosemary and Sage Outperformed Six other Culinary Herbs in Antioxidant and Antibacterial Properties. International Journal of Biotechnology for Wellness Industries 1, 142-151.

Cioffi, M. B., Martins, C., Centofante, L., Jacobina, U., Bertollo and L.A.C. (2009). Chromosomal variability among allopatric populations of Erythrinidae Fish Hoplias malabaricus: mapping of three classes of repetitive DNAs. Cytogenet Genome Res. 125, 132-141.

CLSI, (2011). Clinical and Laboratory Standards Institute. Performance Standards for Antimicrobial Susceptibility Testing; Twenty-First 
Informational Supplement. CLSI document M100-S21. Clinical and Laboratory Standards Institute, 940 West Valley Road, Suite 1400, Wayne, Pennsylvania 19087 USA.

Delaquis, P.J., Stanich, K., Girard, B. and Mazza, G. (2002). Antimicrobial activity of individual and mixed fractions of dill, cilantro, coriander and eucalyptus essential oils. Int. J. Food Microbiol., 74, 101-109.

Dikilitas, M., Guldur, M.E., Deryaoglu, A. and Erel, O., (2011). Anti-oxidant and oxidant levels of pepper (Capsicum аппиит cv. 'Charlee') infected with pepper mild mottle virus. Not. Bot. HortiAgrobo., 39, 58-63.

Dong, P., Zhu, L., Mao, Y., Liang, R., NiuL., Zhang, Y., LiK., and Luo X. (2014). Prevalence and profile of Salmonella from samples along the production line in Chinese beef processing plants Food Contr. 38, 54-60.

Dorman, H., and Deans, S., (2000).Antimicrobial agents from plants, antibacterial activity of plant volatile oils. Journal of Applied Microbiology 88, 308-316.

Enayat, K., Mansour, A., Nasrin, B., Mohammad, T., Eze, H., Oruche, E. and Eze, N. (2013).Interaction of the extracts of three medicinal plants with antibiotics against some antibioticresistant bacteria. Academic Journals 8(28), 1360-1367.

Eze, E.A., Oruche, N.E., Onuora, V.C., and Eze CN. (2013). Antibacterial Screening of Crude Ethanolic leaf Extracts of Four Medicinal Plants. $J$. Asian Sci. Res 3(5), 431-439.

Gavarić, N., Gavarić, J., Kovač, N., Kretschmer, N., Kladar, S., Možina, F. and Bucar. (2015). Natural products as antibacterial agents antibacterial potential and safety of post-distillation and waste material from Thymus vulgaris L., Lamiaceae. Journal of Essential Oil-Bearing Plants, 18(4), 1013-1021.

Gonzales, L.S. and Spencer, J.P., (1998), Aminoglycosides: A practical review. Am. Fam. Physician, 58, 1811-1820.

Gulcin, I., Kufrevioglu, O.I., Oktay, M., and Buyukokuroglu, M.E. (2004). Antioxidant, antimicrobial, antiulcer and analgesic activities of nettle (Urtica dioica L.). J. Ethnopharmacol 90, 205-215.

Handa, S.S., Khanuja, SPS., Longo, G. and Rakesh, D.D. (2008). Extraction Technologies for Medicinal and Aromatic Plants, $\left(1^{\text {st }}\right.$ edn $)$, no. 66. Italy: United Nations Industrial Development Organization and the International Centre for Science and High Technology, Trieste, Italy.

Harley, J.P. and Prescott, L.M. (2002). Laboratory exercises in Microbiology. $5^{\text {th }}$ ed. McGraw-Hill Companies, USA. Pp: 133-192.

Hendriksen, R.S., Vieira, A.R., Karlsmose, S., Lo-Fo-Wong, D.M., Jensen, A. B., and Wegener, H.C.(2011). Global monitoring of Salmonella serovar distribution from the world health organization global foodborne infection network country databank 2007. Foodborne Pathog. Dis. 8: 887900.

Kabir, S.M.L. (2010).The Role of probiotics in the poultry industry. Int. J. Mol. Sci (10), 3531-3546.

Kim IS, Yang MR, Lee OH, Kang SN.(2011). Antioxidant activities of hot water extract from various spices.Int $J$ MolSci (12), 4120-4131.

Ljiljana, P., Stanojević., Mihajlo, Z., Stanković, Dragan, J., Cvetković, Bojana, R., Danilović, J., Stanojević S., Singh, P., and Prakash, A., (2016). Dill (Anethum graveolens L.) seeds essential oil as a potential natural 
antioxidant and antimicrobial agent biological nyssana7 (1), 31-39

Lorian, V. (1996). Antibiotics in Laboratory Medicine. $4^{\text {th }}$ Edn., Williams and Wilkins, Baltimore, London, ISBN: 9780781749831.

Maragathavalli, S., Brindha, S., Kaviyarasi, N.S., B. Annadurai, B. and Gangwar, S.K. (2012). Antimicrobial activity in leaf extract of Neem (AZADIRACHTA INDICA Linn.). I.J.S.N.3 (1), 110-113.

Markov, K., Frece, J., Čvek, D. and Delaš, F. (2009). Listeria monocytogenes idrugikontaminanti $\mathrm{u}$ svježemsiruivrhnjudomaćeproizvodnje s područjagrada Zagreba. Mljekarstvo 59(3), 225-231.

Mohammad Hojjati (2017). Chemical Constituents and Antibacterial Activity of Dill (Anethum graveolens) Essential Oi Proceedings of the 15th ASEAN Conference on Food Science and Technology, Dec. 01, 2017

MoodiHelal Al-Mutairi, Sarah Ali, Salah Mesalhy Aly and Yousef Aldebasi (2016). Antibacterial activity of sider (Ziziphus spinachristi), leaves extract against selected pathogenic bacteria. ejpmr, 3(5): 138-144.

Mounia, T.L., Shuo, H., Sean, T., Corbett, Jean-Francois, L., Svetlana, Y., Lindsay, M., Meyers., Chad, A., Shaw., Sung, Hae, L., Kang., Sau,W.C., Dolores. and Lamb, J.(2010). Identification of De Novo Copy Number Variants Associated with Human Disorders of Sexual Development. Oxoid Ltd, Basingstoke, Hampshire, UK.

Pattnaik, S., Subramanyam, V.R., Bapaji, M. and Kole, C.R. (1997): Antibacterial and antifungal activity of aromatic constituents of essential oils. Microbios. 89, 39-46.

Ramanauskiene K, Savickas A, Bernatoniene J. Ekstrahavimoįtakaskystojonažoliųekst raktokokybein (2004). The influence of extraction method on the quality of the liquid extract of St. John's wort. Medicine Kaunas, (40): 745-749.

Sabahat Saeed., Asma Nai, M. and Perween Tariq (2006). In vitro antibacterial activity of peppermint. Pak. J. Bot. 38(3), 869- 872.

Sallam, K.I., Mohammed, M.A., Hassan, M.A. and Tamura T. (2014). Prevalence, molecular identification and antimicrobial resistance profile of Salmonella serovars isolated from retail beef products in Mansoura. Egypt Food Contr. 38, 209-214

Sanders, CC., Sanders, W.E. and Moland, E.S. (1993). Decimal assay for additivity of drugs permits delineation of synergy and antagonism. Antimicrob. Agents Chemother., 37, 260-264.Singleton, V.L. and Rossi, J.A. (1965). Colorimetry of total phenolics with phosphomolybdic phosphotungstic acid reagents. Am J EnolViticult. 16, 144-158.

Skerget, M., Kotnik, P., Hadolin, M., RiznerHras, A., Simonic, M. and Knez, Z. (2005). Phenols, proanthocyanidins, flavones and flavonols in some plant materials and their antioxidant activities. Food Chem. 89, 191-198.

Smith-Palmer, A., Stewart, J. and FyfeL. (1998). Antimicrobial properties of plant essential oils and essences against five important food-borne pathogens. Lett. Appl. Microbiol.26, 118-122.

Stefanovic, O. and Comic, L. (2012). Synergistic Antibacterial Interaction between Melissa officinalis extracts and antibiotics. J. Appl. Pharmaceut. Sci., 2(1), 1-5.

Sun, T., Xu, Z., Wu, C.T., Janes, M., Prinyawiwatkul W (2007). Antioxidant activities of different colored sweet bell peppers (Capsicum 
annuum L.). J Food Sci, 72, 98-102

Threlfall, E.J., Frost, J.A., Ward, L.R. and Rowe, B. (1996).Increasing spectrum of resistance in multiresistant Salmonella-typhimurium. Lancet 347, 1053-1054.

Valko, M., Rhodes, CJ., Moncol, J., and Izakovic M. (2006). Free radicals, metals and antioxidants in oxidative stress-induced cancer. Mini-review. Chem. Biol. Interact 160, 1-40.

Zhao Y. and Gao Y. (2014). Self-processing of ribozyme-flanked RNAs into guide RNAs in vitro and in vivo for CRISPR-mediated genome editing. $J$ Integr. Plant Biol.56(4), 343-349.

\section{How to cite this article:}

Ashraf A. Abd-El Tawab, Ahmed M. Ammar, Ahmed M. Hamouda, Wafaa A. EL Sebaey, Safinaz A.M. Elhawary and Salma S. El-Deen. 2019. Interaction of Some Plant Extracts with Some Antibiotics against Salmonella from Chickens. Int.J.Curr.Microbiol.App.Sci. 8(03): 2399-2410. doi: https://doi.org/10.20546/ijcmas.2019.803.283 